\title{
Luiz Edmundo de Magalhães (1927-2012)
}

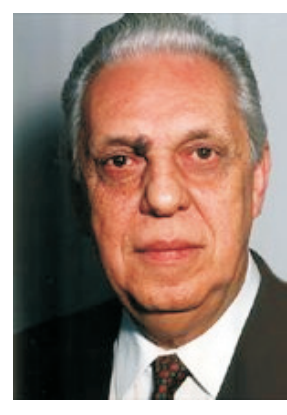

Luiz Edmundo de Magalhães was born on December $5^{\text {th }}, 1927$, in Guaxupé, in the state of Minas Gerais, the son of Lafayette Magalhães and Iracema H. Cerqueira Magalhães, and died on May $22^{\text {nd }}, 2012$, in São Paulo city, at 84 years of age, after 60 years of professional activity. He was married to the naturalist Nicia Wendel de Magalhães; they had six children, 11 grandchildren and one great granddaughter.

At a young age, Luiz Edmundo moved to São Paulo city where he concluded his high school education, and in 1949 enrolled in the Natural History course of the Faculdade de Filosofia, Ciências e Letras da Universidade de São Paulo (Faculty of Philosophy, Sciences and Humanities of the University of São Paulo). He graduated in 1951 and completed his Licentiate degree in 1952, when he was hired as Assistant Professor in the then Departamento de Biologia Geral (Department of General Biology) at the Universidade de São Paulo (University of São Paulo; USP). He received his $\mathrm{PhD}$ in 1958 under the supervision of Prof. Crodowaldo Pavan, with a doctoral thesis entitled "Fluctuations in the population size of Drosophila of the willistoni sub-group in the islands of Angra dos Reis". He received the title of Professor Livre Docente in 1972, with a thesis entitled "A study of selection of the ebony mutant in some phases of the reproductive life cycle in Drosophila melanogaster". In 1982, he became Full Professor at USP, a position that he held until his retirement in 1988.

In 1949, Luiz Edmundo started his research activities under the supervision of Prof. Crodowaldo Pavan, and participated in various projects on flies of the genus Drosophila. Soon after earning his $\mathrm{PhD}$, from April 1959 to June 1960, he undertook post-doctoral work at the University of Texas, in Austin, under the supervision of Prof. Marshall R. Wheeler. As a result of this work, he published important reviews on the systematics of Drosophila, especially the saltans group.

Upon returning to Brazil in 1960, his interests switched from taxonomy to the study of the dynamics of lethal genes, in natural populations of $D$. willistoni in the islands of Angra dos Reis, and in population cages. Around 1965 , he abandoned his studies of lethal genes without having achieved his original aims for this work. An article that he recently co-authored with Dr. Carlos R. Vilela, on the period from 1943 to 1959 , which they refer to as "The Golden Age of Drosophila Research at the University of São Paulo", will be published in the near future.
From 1965 onwards, research on Drosophila gradually waned in the Department of General Biology until his laboratory was the only one working on this subject. These were difficult years, during which he supervised studies on the viability of lethal genes and morphological mutants in D. melanogaster, and the rate of natural dispersion as well as sex-ratio deviation in $D$. willistoni, as part of an effort to develop new lines of research.

From February 1970 to March 1972, he took leave from the Department of Biology to serve as Full Professor of General Genetics in the Departamento de Genética da Faculdade de Ciências Médicas e Biológicas de Botucatu (Department of Genetics of the Faculty of Medical and Biological Sciences of Botucatu) in São Paulo state. In March 1972, he returned to the Department of Biology and shortly thereafter spent a brief period (April to September, 1972) as Associate Professor in the Department of Zoology at the University of Texas at Austin, during which time he received training in the electrophoresis of proteins. In 1973, upon returning from Texas, he continued his efforts to establish a laboratory focused on electrophoresis of proteins, but also briefly returned to taxonomic studies during a one-year visit by Chana Malogolowkin Cohen, who at that time was working in Israel. In March, 1975, he again took leave from the Department to become Rector of the Universidade Federal de São Carlos (Federal University of São Carlos; UFSCar) for four years.

In February, 1976, when Drosophila research in his laboratory had virtually ceased, Luiz Edmundo still had available some funds that he had received from the Conselho Nacional de Desenvolvimento Científico e Tecnológico (National Council for Scientific and Technological Development; $\mathrm{CNPq}$ ) as part of the Programa Integrado de Genética (Integrated Program in Genetics; PIG). With this funding, the infrastructure of the laboratory was modernized and studies were initiated on natural populations of cactus-dwelling Drosophila species, with flies being collected from various dry regions of South America along a transect that ranged from the north-eastern Brazilian state of Rio Grande do Norte to the foothills of the Andes, in the Argentine chaco.

In addition to his research interests, throughout his career as a faculty member, Luiz Edmundo took a keen interest in teaching, and taught numerous disciplines and courses, in addition to publishing a book entitled Citologia e Genética (Cytology and Genetics) that he co-authored with Prof. Renato Basile. This book went through 19 editions and, from 1973 to 1981, was one of the most widely used text-books in Brazilian high schools. He also edited books and wrote various book chapters, in addition to trans- 
lating books that included The Genetic Code ( $O$ Código Genético) by Isaac Asimov and Genetics and Evolution (Genética e Evolução) by C. Petit and G. Prevost.

He was Head of the Department of Biology (1982 1985 ) and Director of the Institute of Biosciences - USP (1985-1988). He was a scientific adviser to the Fundação de Amparo à Pesquisa do Estado de São Paulo (State of São Paulo Research Foundation; FAPESP) from its foundation in 1962, and acted as adviser to the Scientific Director (1981-1982). At CNPq, he was a member of the evaluation committee (1979-1980), and coordinated the program Genética, Evolução e Ecologia de Insetos (Genetics, Evolution and Ecology of Insects) from 1974 to 1978, as part of the Integrated Program in Genetics.

Luiz Edmundo was editor-in-chief of Ciência e Cultura, the official journal of the Sociedade Brasileira para o Progresso da Ciência (SBPC) for the period 1970-1971. He was also a member of the editorial board of Genetics and Molecular Biology from 2002 to 2012.

He was actively involved in several scientific societies. A founding member of the Sociedade Brasileira de Genética (Brazilian Society of Genetics; SBG), he served as member of the Board of Directors and was President of the society from 1982-1984. He was secretary general to the SBPC for three terms (1973-1975, 1975-1977 and 1985-1987). He was a Founding Member of the Academia Paulista de Ciências (São Paulo Academy of Sciences; ACIESP).

In addition to the time spent in Botucatu and as Rector of UFSCar, Luiz Edmundo was also Visiting Professor at the Universidade Federal de Sâo Paulo (Federal University of São Paulo; UNIFESP) from 1996 to 2001, where he served as Technical Director and Research Coordinator of the Centro de Desenvolvimento de Modelos Experimentais para Medicina e Biologia (Center for the Development of Experimental Models for Medicine and Biology; CEDEME).

In recent years, Luiz Edmundo was engaged in gathering and registering historically important events in Brazilian science. He was working on this project until shortly before his death, when he completed a book entitled $H u$ manists and Scientists of Brazil that is currently being edited and will soon be published in three volumes by the SBPC.

Fábio de M. Sene Departamento de Biologia Faculdade de Filosofia, Ciências e Letras de Ribeirão Preto Universidade de São Paulo, Ribeirão Preto, SP, Brazil 